\title{
SOME AMERICAN SYRPHID FLIES
}

\author{
By Frank M. Hull \\ University of Mississippi
}

Recent collections of flies submitted to the author contain a number of neotropical species of Baccha which are undescribed. This paper gives the descriptions of these flies. A species of Rhinoprosopa is included.

Baccha balboa n. sp.

A petiolate species, the face without tubercle, the anterior margin of the wing narrowly brown. Related to bigoti Austen but without the reddish spots on the fourth segment and with different pattern upon the wing. Length $10 \mathrm{~mm}$.

Male. Head: the vertex is polished black, rather flat, the long black pile lies in a single row. The front is black, with faint bluish reflections and protuberant just in front of the narrow antennal callus; the sides of the front are diffusely yellowish grey pollinose; the frontal pile is long and fine and black. The face is black with faint bluish reflections, nearly straight in profile but retreating and without tubercle; the sides are widely yellowish grey pubescent with similarly colored pile. The antennæ are dark brown, the third segment and apex of the second segment reddish below; arista dark brown. The occiput is yellowish grey pollinose with fine, white, non-scalose pile which becomes blackish near the vertex. The posterior eye margin is not indented in the middle but the eye is developed above so that the occiput can not be seen laterally on the upper third. Thorax: the mesonotum is polished shining including the scutellum; the humeri and the post calli are shining, dark sepia brown; there are no vittæ present and no pollen. The mesonotal pile is fine, erect, fairly long and blackish without anterior collar, the pile becoming shorter and pale yellow in front of the scutellum. The scutellar pile is fine and long and yellow; the ventral fringe consists of fifteen or more pairs 
of long, pale yellow hairs ; the pleura are black and somewhat brassy down the middle, their pile thick, long and pale yellow. The squamæ are white, the fringe and border pale yellow, the halteres dark brown. Abdomen: slender and petiolate, first segment wholly shining greenish black with long, abundant, fine yellow pile on the sides. The second segment is light brownish red, shining and with a slender, medial, brownish black line running almost the full length of the segment stopping close to the base; this segment is nine times as long as its least width; the width at the apex is a little more than one and one-half times as long as the least width, the basal width barely greater than the apical width. The third segment has a pair of large, pale, brownish red, elongate, posteromedially produced spots upon the base of the segment which are separated by light brown in the middle; the remainder of the segment except the posterior border is nearly opaque black, the posterior margin shining. The fourth and fifth segments are wholly shining black; the fourth segment is not quite twice as long as wide. The sides of the second segment have long, fine, abundant pile directed outwardly; there is similar but shorter pile on the sides of the third segment except the posterior fifth where it is appressed; there is still shorter erect pile on the sides of the basal half of the fourth segment; the erect pile on the third and fourth segments is reddish yellow but on the second segment it is chiefly blackish except at the immediate base. All other pile of the abdomen is black. Legs: the anterior and middle femora are light reddish brown; their tibiæ are pale brown becoming a little more yellowish close to the apices and the base. The anterior tarsi are brown, the middle tarsi entirely yellow. The hind femur is sepia except at the extreme apex; hind tibiæ black, the base narrowly yellowish, its pile black. The hind basitarsi are black on the basal half with sepia pile, diffusely shading in the middle to pale yellow; the remaining segments are pale yellow. The pile of the hind femur is sepia to black. Wings: pale brownish hyaline; the pterostigma and the anterior margin of the wing to the end of the submarginal cell is dark 
brown. The dark brown margin extends back along the submarginal cell a distance basally beyond the end of the subapical cross vein equal to the petiole of the first posterior cell. The marginal cell except at the apex of the wing, the costal cell and a large diffuse spot in the middle of the wing are more yellowish or reddish brown. The central wing spot extends only narrowly beyond the anterior cross vein, which cross vein lies close to the base of the discal cell, and borders the cubital cross vein. The whole subcostal cell is dark brown; alulæ quite wide.

Female. Similar to the male, the sides of the front greyish white pollinose; the ground color of the front is strongly shining bluish black but in the middle it appears to be more purplish black; the occipital pile is confined to a single, neatly formed row of long, pale yellow hairs which become reddish brown above and nearly whitish close to the oral margin where there are several rows of hairs. Notopleural bullus rather conspicuous, the posterior part of the notopleura whitish pollinose. The mesonotal pile is a little shorter than in the male, the pleura have an obscure brownish red stripe down the middle; the pteropleura are wholly metallic black; the halteres have a yellowish brown to reddish knob. Upon the abdomen the medial dark brown stripe of the second segment appears to be wanting and the basal spots of the third segment smaller and more diffuse.

Holotype: a male, La Suiza, Costa Rica, 24; Pablo Schild; allotype: a female with the same data without numeral; there is also a paratype male and female with the same locality and collector. Type and allotype in the collection of Dr. A. L. Melander.

\section{Baccha zephyrea n. sp.}

A slender species related to argentina Curran, but with different pattern. Length $8 \mathrm{~mm}$.

Male. Head: the vertex is quite protuberant, black, the black pile in a single row; the bluish black front is prominently transversely striate and abundantly long black pilose on the sides but rather bare in the middle and the sides of the front are linearly yellowish white 
pollinose; the lunate antennal callus is yellowish brown, blackish in the middle. The face is metallic blackish on the upper half becoming light yellowish brown on the tubercle and the cheeks; the middle of the cheeks with a brownish spot. The antennæ are yellowish brown. Thorax: the mesonotum is strongly brassy black, coppery just in front of the postcalli; the lateral margins and the notopleura appear to be yellowish brown in ground color but so dark as well as metallic in reflections that they do not contrast greatly with the disc of the mesonotum. The mesonotum has a pair of short, obscure, brownish red pollinose vittæ and some sparse, similar pollen in front of the scutellum. The mesonotal pile is sparse', short and apparently light in color; pleura metallic black, only the posterior part of the mesopleura and the anterior part of the pteropleura are obscure yellowish brown; the squamæ are light yellow, the stalk of halteres pale yellow with reddish brown knob. Abdomen: very slender and petiolate, the first segment black, its protuberant lateral margins light brownish yellow. The spots of the abdomen are sharp and distinct but are for the most part pale brownish orange. On the sides of the base of the second segment there is a quite long spot of light color, occupying about a third of the length of the segment sharply and distinctly separated by black in the middle; beginning just before the middle of the segment there is a long, complete pale band occupying a little more than one-fourth the length of the segment; remainder of this segment shining black. The second segment is fifteen times as long as its least width and not quite twice as wide at apex and just twice as wide as its base. The third segment has two long, complete bands of light color, one on the base, one beginning just before the middle of the segment, divided by a narrow brown line; the fifth segment is wholly black; the hypopygium is prominent. The pile along the second segment is very sparse and short. Legs: the anterior legs are entirely brownish yellow, the middle legs missing. The posterior femora and tibiæ are very pale yellowish brown, their tarsi almost as light; the dorsal surface of these tarsi is pale brown with 
brown pile; the pile of the hind tibiæ is quite sparse, quite short and dark in color. Wings: not quite hyaline; the pterostigma is yellowish brown, the costal and basal cell slightly paler than the remainder of the wing; there is no alula, not even a trace.

Holotype : a male, Villarica, Paraguay, August, 1938; F. Schade collector. In the collection of Dr. A. L. Melander.

\section{Baccha ursula n. sp.}

A dark, sepia brown species with sepia brown wings. Related to danaida Hull but with differently shaped spots on the abdomen. Length $11.5 \mathrm{~mm}$.

Male. Head: the vertex is dully shining black, considerably raised, its pile black and situated in a single row. The lateral margin of the eye is considerably incised on the posterior surface; the occipital pile is fine and yellowish white. The front is black, moderately shining, faintly brassy in some lights with the lateral margins narrowly but diffusely yellowish. In an oblique light the middle of the front is very dark brown pollinose; the preantennal callus is shining black in the middle and narrowly yellow above each antennæ. The face has a reddish brown tubercle; the sides of the face and the area below it are light brownish yellow; the middle of the face above the tubercle is diffusely brownish black with little angular spots which are slightly more widely separated and lie slightly before the middle of the segment. Fourth segment with a pair of similar though slightly more obscure, or diffuse and vittate, or longitudinal, oval spots which also lie just before the middle of the segment. Fifth segment without spots. The middles of the second, third and fourth segments are only sub-opaque when viewed obliquely. Legs: the anterior and middle femora are yellowish or reddish brown becoming slightly darker towards the base, their tibiæ and tarsi are entirely pale brownish orange. The hind femora are light reddish sepia, their tibiæ similar but a little darker in the middle and the pile of the tibiæ more nearly blackish in the middle. The base of the hind basitarsi is brown with 
sepia brown pile, the remainder of these tarsi light brownish yellow with golden pile. Wings: dark sepia brown throughout, the pterostigma and the basal portion of the marginal cell a little bit darker. Alulæ well-developed, long and narrow.

Female. Similar to the male, the vertex, however, is not especially raised; the sides of the front are also diffusely brownish yellow, the middle dark brown pollinose; the first two segments of the antennæ are reddish brown in color, rather darker than in the male. Thorax: the mesonotum is bright coppery violaceous in color, the widely separated yellowish brown vittæ are somewhat more narrow, the lateral margin a little more yellowish; the light colored areas of the pleura are more yellowish and extend across the pteropleura and include much of the metapleura. The squamæ are distinctly yellowish brown. The scutellum is lighter in color than in the male, is brownish yellow especially around the margins and the base; its pile is also sparse but is shorter; there is no ventral fringe. Abdomen: much wider and even more flattened than in the male; the sides of the fifth and sixth segments are somewhat emarginate; the second segment is almost rectangular, but is a little wider at the apex than at the base. The fourth segment has parallel sides. The apical portion of the abdomen is considerably wider than in the male; the second segment is also wider; the spots upon the second segment are linear, upon the third segment they are very short oval or subcircular but irregular and diffuse; on the fourth segment the spots are linear, smaller and much more obscure; on the fifth segment there is a trace of linear, yellowish brown spots. Legs similar to the male; the wings are similar to the male, quite dark, the whole marginal and submarginal cells slightly darker than the posterior part of the wings; there is a faint streak of light color in the costal cell and along the base of the vena spuria. These streaks may be abberant.

Holotype: a male, Villa Rica, Paraguay, September 1938 ; F. Schade ; allotype : a female, same locality, February $1940 ;$ F. Schade. There are two paratype males, 
Feb. 1940 and Feb. 1941 from the same locality. Holotype and allotype in the collection of Dr. A. L. Melander.

Baccha cybele n. sp.

A black species, the wings sepia brown with only the apical fourth hyaline. Second, third and fourth segments of the hind tarsi white. Related to clarapex Wiedemann. Length $9.5 \mathrm{~mm}$.

Male. Head: the vertex is bluish black and shining, moderately raised, the black pile lies in a single row; the posterior lateral eye margins are deeply incised in the middle; there is a long row of silvery occipital pile behind, fine and non-scalose, long in the middle becoming blackish towards the top of the occiput; along the indented area of the eye there is a double row of long fine black hairs which are replaced by white ones on the lower part of the occiput. The occipital pollen is greyish white but the black hairs arise from minute black punctate spots. Front black, faintly bluish and in some lights with an azure blue reflection. The upper third of the front is opaque black bordered by brown pollen and in turn the brown pollen bordered with a spot of silvery pollen which lies on the upper eye margin and is visible only from above. The antennal callus is large, shining brownish black, narrowly and diffusely brownish yellow along the sides in the middle of the face only. The cheeks are metallic black; the sides of the face are widely white pubescent or pollinose; the tubercle is rather sharp, gently sloping above, somewhat more abruptly below. The antennæ are dark brown, reddish brown below at the base of the third segment. The arista is dark brown but lighter at the immediate base. The frontal pile and nearly all of the basal is black. Thorax: the mesonotum is black, moderately shining with a pair of very obscure, reddish brown pollinose spots on either side of the middle of the anterior margin ; the entire anterior margin is more narrowly but similarly pollinose. There is a still more obscure, narrow, greyish streak down each side of the mesonotum reaching nearly to the transverse suture. The pleura are wholly metallic black, thinly whitish polli- 
nose and with long sparse yellowish white pile. The scutellum is black with only a few, long, fine black hairs; the ventral fringe consists of seven or eight pairs of moderately long black hairs. There is an anterior mesonotal collar of pale yellow hairs. The squamæ are light brown, the halteres pale brown with reddish knob. Abdomen: petiolate, shining black, the first segment with slight bluish reflections, its sides with thick long yellowish white pile and some black hairs both dorsally and anteriorly. The second segment is a little bluish along the sides and narrowly along the apical margin. There is a prominent, subapical, opaque black annulus which is prolonged and produced forward in the middle to within a short distance of the base. The second segment is slightly over three times as long as its least width. The third segment is considerably wider, especially at the apex and with a pair of obscure, opaque black triangles on either side and medial opaque stripe. The fourth segment is similar, the opaque areas less distinct. On both the third and fourth segments the opaque areas are only visible from an oblique posterior or anterior view. The fifth segment is wholly shining black; the pile of the abdomen is black beyond the first segment except for a very few white hairs on the sides of the second segment near the base. Legs: the anterior and middle femora and tibiæ are brownish black; their apices and bases of the tibiæ are narrowly reddish brown. The anterior and middle tarsi are dark brown; the hind femora, except the narrow base and apex and the hind tibiæ except the extreme base, are black, both with black pile. The basal three-fourths of the hind basitarsi are black and black pilose; remainder of these tarsi with nearly similarly colored pile. Wings: sepia brown throughout except upon the apical fifth; the brown color fills the discal cell. The alulæ are wide and welldeveloped; there is an abnormality in the second longitudinal vein near the end of the marginal cell in both wings; it consists of a spur directed obliquely outward cutting half way across the submarginal cell.

Holotype : a male, Villa Rica, Paraguay, Nov. 1938 collected by F. Schade; one paratype male, Dec. 1936 but 
otherwise the same data. Type in the collection of Dr. A. L. Melander; paratype in the author's collection.

Baccha duida n. sp.

A quite slender fly with dilute, light brown wings and without alulæ. The third vein is deeply drawn down posteriorly as it reaches the wing apex. Length $9.10 \mathrm{~mm}$.

Male. Head: face and front light brownish yellow but medium brown in the center of the front which merges into a blackish, medial, elongate spot just above the antennæ. The antennæ are short, the third segment thickened and rounded and light brown; the basal segments are darker, their pile black. The front and facial pile is black, the face narrow, the creases deep, the face barely more narrow ventrally. The vertex is raised and rather shining black, its black pile is situated in a single row; the posterior part of the vertex is brownish pollinose. The upper occipital pile is reddish golden and brassy on the sides. Thorax: mesonotum shining black with three slender, reddish-brown pollinose vittæ; the outer one may possibly be divided into two posteriorly. The humeri, the lateral margins, the post calli and all of the scutellum, all the pleura except the posterior part of the metapleura, the lower part of the sternopleura and the anterior part of the mesopleura, are all light reddish brown; the remainder of the pleura are dark brown and the disc of the scutellum viewed from the side appears dark brown. The mesonotal pile is sparse, fine, erect and brown. The ventral scutellar fringe consists of six or seven short black hairs. Abdomen: quite slender and dark brown becoming black on the posterior portion of the segments; the second segment has a pair of narrowly separated, elongate, orange brown spots beginning just past the middle and margined dorsally with opaque black and extending down the lateral margins; laterally these spots show a slight posterior indentation. The third segment has a similar pair of spots in the middle, longer, anteriorly attenuated and with V-shaped notch posteriorly. The fourth segment has a similar pair of spots of about the same size. The spots on both the third and 
fourth segments show some indication of running narrowly and obscurely to the base of the segment; the basolateral areas of the segments are, however, shining brownish black; fifth segment shining black. The pile along the sides of the second abdominal segment is very sparse and short but a little longer on the posterior half ; the pile on the sides of the first segment is sparse and moderately long in the corners and brownish black. Legs: anterior pair light brownish yellow with pale pile; medial pair light brown, the lateral fringe of the middle femora moderately long and reddish brown. The hind femora are pale reddish brown with wide, obscure, darker brown subapical bands. The hind tibiæ are slender, preapically compressed, straight and reddish brown with, in the middle, a brownish yellow band. The hind basitarsi are slender and entirely brown with dark brown pile on the dorsal surface and brownish yellow pile below; last segments missing. The pile of the hind tibiæ and femora is brownish black. Wings: slender, and light brown including the costal cell; stigmal cell dark brown, lighter below the costal cell; the third vein is arched and considerably drawn down apically; alulæ quite absent; anal lobe almost hyaline.

Holotype : a male, Mt. Duida, Venezuela, Dec. 1, 1928. Accession 25500, 423; Tate. In the American Museum of Natural History.

\section{Rhinoprosopa sycorax n. sp.}

A yellow and brown species with pale yellowish wings. Related to lucifer Hull. Length about $9 \mathrm{~mm}$.

Female. Head: the vertex is brassy black, the ocelli set off by a crease touching their margins; the vertical pile is short and black. The front is brownish black in the middle with the sides ochraceous yellow and in the midline there is a brassy, linear stripe wider on the upper half ; the face is reddish sepia in the middle with a very low pinched tubercle; the sides of the face and cheeks are light yellow. The face is triangularly produced forward as is characteristic of the genus but not as much as in anea Hull. The antennæ are slightly elongate and reddish orange; the dorsal surface of the third segment is 
blackish, the arista black. The pile of the front is fine and sparse and black; the sparse facial pile is whitish; the pile of the occiput is yellowish brown becoming black near the top. Thorax: the mesonotum is moderately shining greenish to brassy black; the whole notopleura and the humeri and a wide stripe down the pleura are light reddish yellow; the postcalli and the scutellum are brownish yellow; the scutellum in oblique view appears to be darker brown upon the disc, its pile is quite sparse and short and blackish with here and there a reddish hair; the ventral scutellar fringe apparently is absent. The squamæ are dark sepia, the halteres reddish brown. $A b$ domen: first segment brownish yellow narrowly on the posterior margin with a few long, reddish brown hairs on the sides of the base; the second segment is sepia brown with very obscure, oblique oval spots on each side of the middle of the segment enclosed by obscure opaque color. The third segment is almost the shape of an equilateral triangle; it is sepia brown with obscure, reddish brown, quite oblique vittæ proceeding from the base of the segment and running to the sides and then reaching the sides of the segment close to the posterior segment. The area in the middle behind these vittæ constitutes a definitely opaque brown triangle in which, however, the posterior margin is obscure. The fourth segment has a complete, arcuate, rather narrow but reddish brown band which is somewhat lighter than the preceding vittæ; the area behind is obscurely opaque. The fifth segment is obscurely lighter brown in the corners and with a suggestion of an arcuate opaque band behind. Legs: anterior and middle legs entirely yellow; basal half of hind femora yellow, the apical half brown. The posterior tibiæ and tarsi are pale reddish brown with dark brown pile. Wings: light brownish yellow throughout, the pterostigma of a slightly darker shade of yellow brown and the apex of the marginal and submarginal cells with a more distinctly brown but very diffuse spot which shades gradually into the paler color. Alulæ well-developed though not much wider apically than basally.

Holotype: a female, La Suiza, Costa Rica, 12-IX; Pablo Schild. In the collection of Dr. A. L. Melander. 

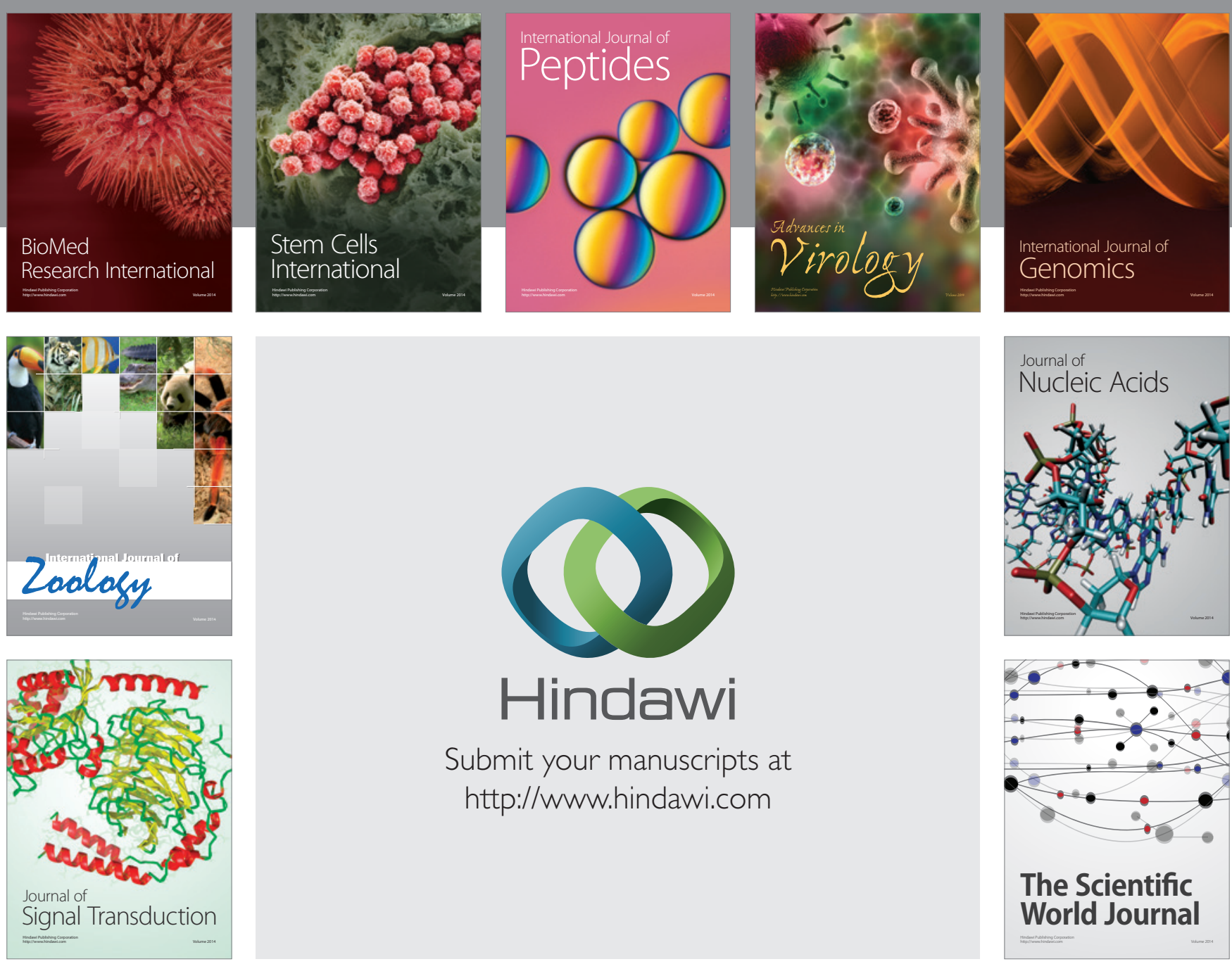

Submit your manuscripts at

http://www.hindawi.com
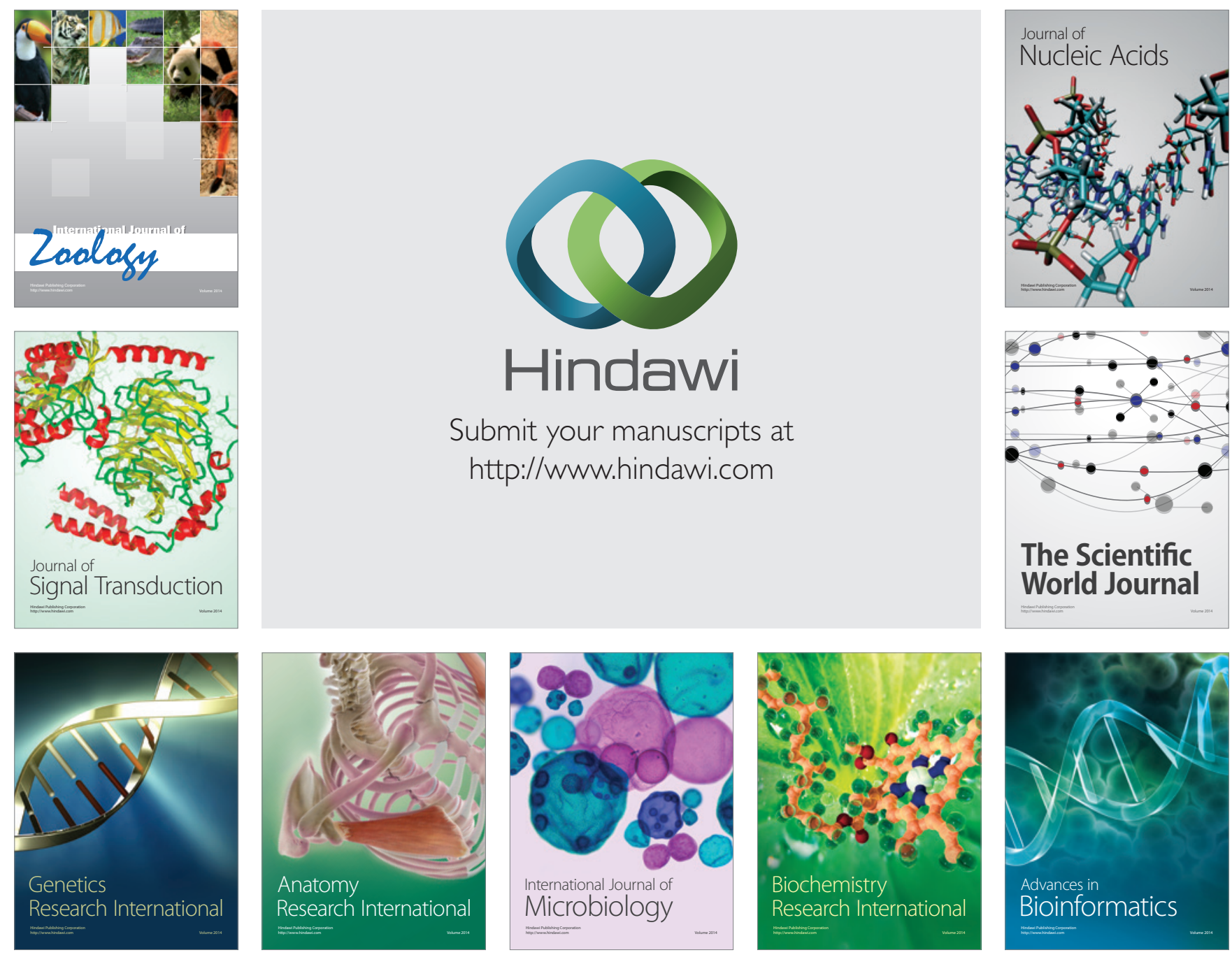

The Scientific World Journal
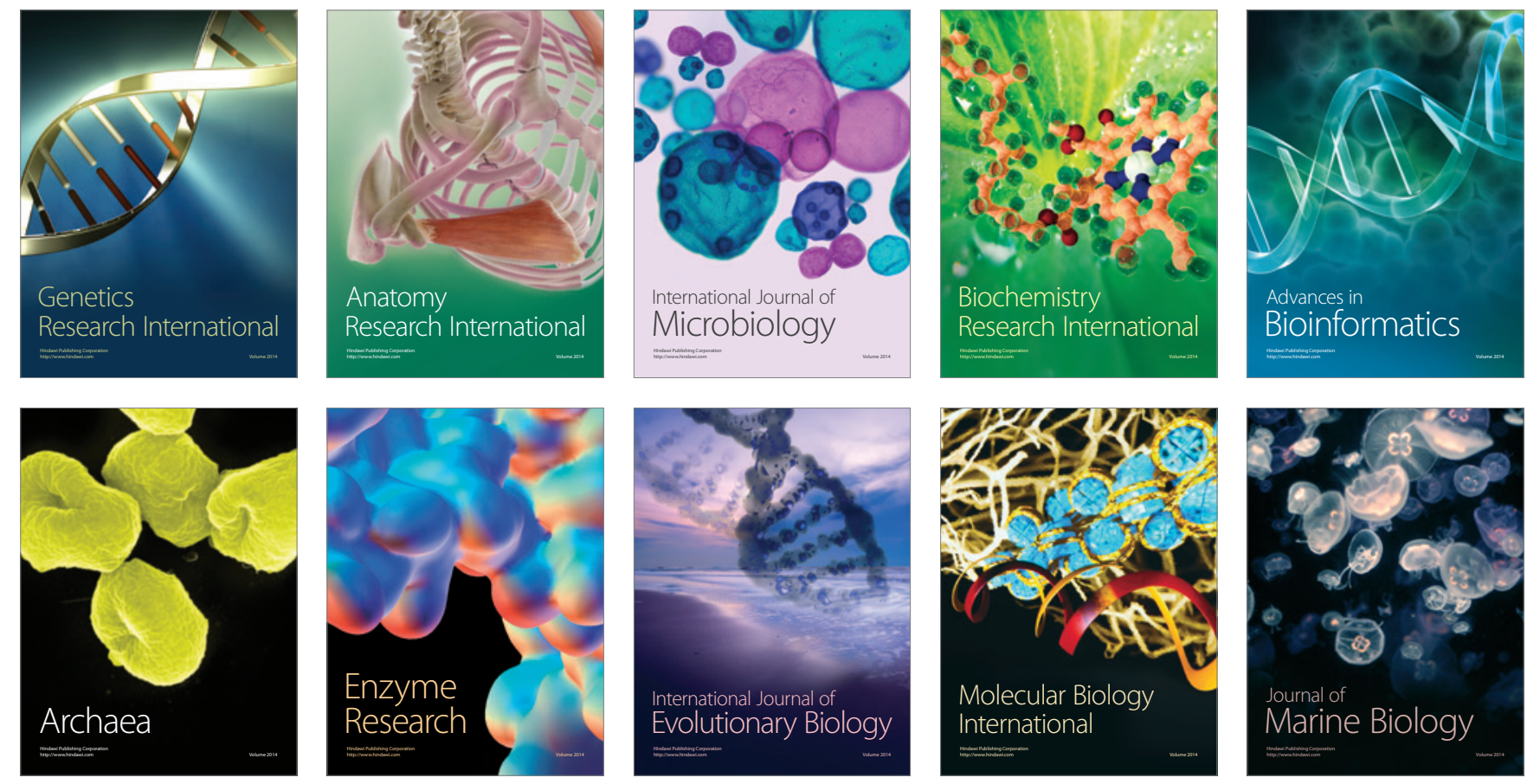